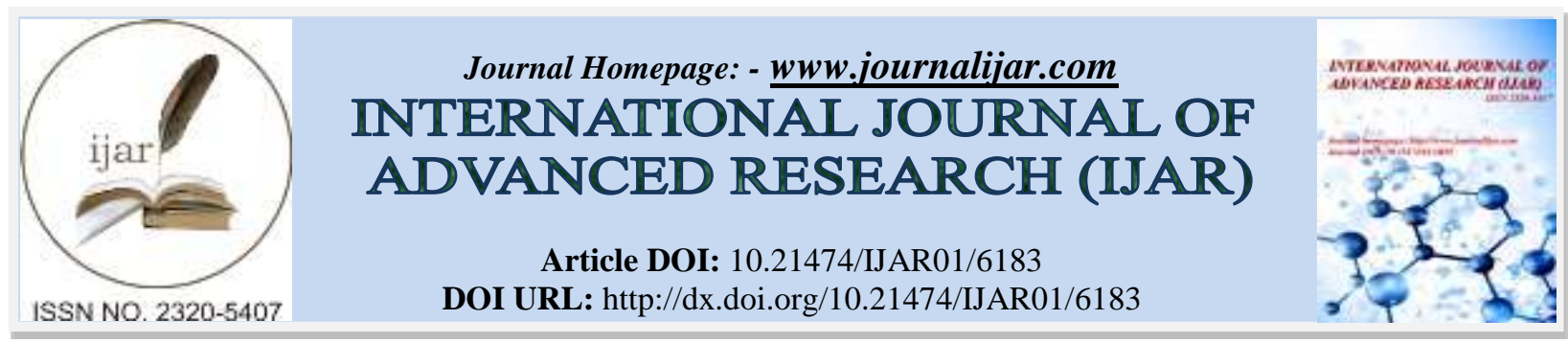

RESEARCH ARTICLE

\title{
FACTORS INFLUENCE ON POOR ASTHMA CONTROL AMONG MEDICAL CLINIC PATIENTS SEEN AT TEACHING HOSPITAL BATTICALOA.
}

"Lokeesan V and Joseph J.

Department of Supplementary Health Sciences, Eastern University, Sri Lanka.

\section{Manuscript Info}

Manuscript History

Received: 01 November 2017

Final Accepted: 03 December 2017

Published: January 2018

Key words:-

Asthma, Batticaloa, Adult.

\begin{abstract}
Objective: To identify the influencing factors of poor asthma control among adult asthmatic patient teaching hospital Batticaloa.

Method: A cross sectional descriptive study conducted among 207 sample of asthmatic adult clients aged above 18 years who visited medical clinic teaching hospital, Batticaloa. Modified version of the 2007 NAEPP expert panel report guideline used to classified asthma control as well control and not well control by using four parameters: daytime symptoms, nighttime symptoms, interference with normal activity, and use of short-acting $\beta 2$-agonists. Data were statistically analyzed using the Statistical Package of Social Science (SPSS v.20) software.

Result: Analysis revealed that most of the patients (71\%) are well controlling their asthma. Poor controlled patient (35\%) told that weather is the triggering factor for their asthma. Patient who have regular clinic visit have well controlled their asthma. Most of the not well-controlled patient $(72.8 \%)$ does not received health education. Inhaler usage and appropriate time of taking medication were statistically significant with not well-controlled asthma.

Conclusion: Most of the Adult asthmatic patients well control their asthma symptoms. Clients under not well-controlled category not only get proper health education but also they does not have regular clinic follow up which may leads to exacerbation of asthma than well controlled group.
\end{abstract}

Copy Right, IJAR, 2018,. All rights reserved.

\section{Introduction:-}

Noncommunicable diseases (NCDs) kill 40 million people each year. In every years, 15 million people die from a NCD between the age of 30 and 69 years. Respiratory diseases are the third leading cause of premature death nearly 3.9 million people per year. NCDs threaten progress towards the 2030 agenda for Sustainable development, which includes a target of reducing premature deaths from NCDs by one-third by 2030 (1).

Asthma is one of the major noncommunicable disease, 235 million people currently suffering from asthma. According to the latest World Health Organization estimates, released in December 2016, there were 383000 death due to asthma in 2015. Asthma is a public health problem not just for high-income countries; it is occurs in all countries regardless of the level of development. Most asthma related death occur in low and lower middle income 
countries. Asthma is under diagnosed and under treated problem in all countries. It creates substantial burden to individuals and families and often restricts individuals' activities for a lifetime (2).

Asthma is a common chronic airway disorder characterized by periods of reversible airflow obstruction known as asthma attacks. Airflow is obstructed by inflammation and airway hyper reactivity (contraction of the small muscles surrounding the airways) in reaction to certain exposures. Exposures include exercise, infection, allergens (e.g., pollen), occupational exposures (e.g., chemicals), and airborne irritants (e.g., environmental tobacco smoke). Symptoms may include wheezing, coughing, shortness of breath, and chest tightness. It is not clear how to prevent asthma from developing and there is no cure. Yet the means to control and prevent exacerbations in persons who have asthma are well established in evidence-based clinical guidelines (8).

According to the latest WHO data published in May 2014 Asthma Deaths in Sri Lanka reached 2,953 or 2.33\% of total deaths. The age adjusted Death Rate is 13.98 per 100,000 of population ranks Sri Lanka got twentieth place in the world (4). Sri Lanka health at glance 2008 reveal leading causes of hospital admissions due to respiratory system, excluding disease of upper respiratory tract on the year 2007 the rate was 8.7\% (5). In Batticaloa district, 19 $\%$ of the people are suffering from chronic illnesses. In that, asthma prevalence is $2.8 \%$ in total population in Sri Lanka. (6)

There is very limited data on asthma epidemiology from the developing world, including Sri Lanka. The expected outcome will bring out the asthma control in patient attending teaching hospital Batticaloa. It will be helpful to enhance their quality of life and the management who are suffering from asthma. No any studies performed in Batticaloa District, regarding factors influence on poor asthma control.

\section{Methodology:-}

It is a cross-sectional descriptive study, which was carried out in Teaching hospital, Batticaloa. The study population considered of the asthmatic patients attending the medical clinic during the year of 2017. Asthmatic patient above 18 years old were included for the study, on the other hand asthmatic patients who under 18 years old and not supported to the study were excluded. A structured interviewer administered questionnaire (IAQ) was used to collect information.

\section{Data collection:-}

Data collection was done by the researcher and his trained team, they assisted in filling the questionnaires. The participants were sensitized thoroughly about the purpose of the study. The interviewer administered questionnaire (IAQ) was prepared in English language and translated into Tamil language.

\section{Data analysis:-}

The data analysis done by using Statistical Package of Social Science (SPSS v.20). Following the guidelines in the NAEPP Expert Panel Report 3 (7), we classified asthma control as well controlled, not well controlled by using four parameters: daytime symptoms, nighttime symptoms, interference with normal activity, and use of short-acting $\beta 2$ agonists (SABA) (Table 1). This is a modified version of the 2007 NAEEP guidelines because it does not include very poorly controlled option and pulmonary function measures.

Table 1:- Classification of asthma control modified from the National Asthma Education and Prevention Program Expert Panel Report 3 guidelines.

\begin{tabular}{|l|l|l|}
\hline Impairment & Well controlled & Not well controlled \\
\hline Symptoms & $\leq 2$ days/week & $>2$ days/week \\
\hline Nighttime awakenings & $\leq 2 /$ month & $1-3 /$ week \\
\hline $\begin{array}{l}\text { Interference with } \\
\text { normal activity }\end{array}$ & None & Limitation \\
\hline Short-acting $\beta 2$-agonists & $\leq 2$ days/week & $>2$ days/week \\
\hline
\end{tabular}

In addition to the asthma control questions, the questionnaire included questions on age, sex, race, area residence, educational level, marital status, employment status, monthly income smoking status, duration of the disease and knowledge on asthma control. 


\section{Ethical consideration:-}

Ethical clearance for the study was obtained from the Ethical Review Committee of Faculty of Health-Care Sciences, Eastern University, Sri Lanka. Permission for data collection was obtained from director teaching Hospital Batticaloa and relevant medical clinic consultants.

\section{Results:-}

Figure 01 Prevalence of level of asthma control.

\section{Level of Asthma control}

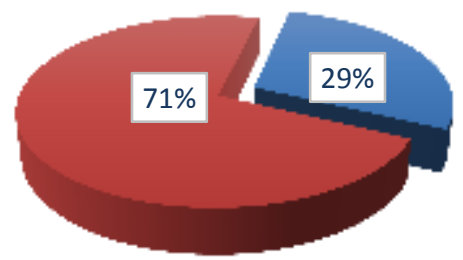

Not well controlled

Well controlled

Table 2:- Socio-economic and demographic characteristics and health conditions among not well controlled asthma group.

\begin{tabular}{|c|c|c|}
\hline Variables & Levels & $\mathrm{N}(\%)$ \\
\hline \multicolumn{3}{|l|}{ Age (years) } \\
\hline & $18-34$ & $3(5.1)$ \\
\hline & $35-64$ & $35(59.3)$ \\
\hline & $>65$ & $21(35.6)$ \\
\hline & Female & $41(69.5)$ \\
\hline & Male & $18(30.6)$ \\
\hline \multicolumn{3}{|l|}{ Ethnicity } \\
\hline & Tamil & $44(74.57)$ \\
\hline & Muslim & $15(25.43)$ \\
\hline \multicolumn{3}{|l|}{ Education } \\
\hline & Less than grade 5 & $19(32.2)$ \\
\hline & Grade 5 to GCE O/L & $33(55.9)$ \\
\hline & Passed GCE A/L & $07(11.9)$ \\
\hline \multicolumn{3}{|l|}{ Marital status } \\
\hline & Married & $44(74.6)$ \\
\hline & Unmarried & $06(10.2)$ \\
\hline & Separated & $02(3.4)$ \\
\hline & Widowed & $7(11.9)$ \\
\hline \multicolumn{3}{|l|}{ Monthly income } \\
\hline & Less than Rs.5,000.00 & $16(27.1)$ \\
\hline & Rs.5,001 - Rs.9,999 & $16(27.1)$ \\
\hline & Rs.10,000 - Rs.14,999 & $15(25.4)$ \\
\hline & More than Rs. 15000 & $12(20.3)$ \\
\hline \multicolumn{3}{|l|}{ Family members having asthma } \\
\hline & $\begin{array}{l}\text { Yes } \\
\text { No }\end{array}$ & $\begin{array}{l}26(44.1) \\
33(55.9)\end{array}$ \\
\hline \multirow[t]{4}{*}{ Hospital admission during last year } & $1-2$ & $22(37.3)$ \\
\hline & $3-4$ & $03(5.1)$ \\
\hline & $>5$ & $02(3.4)$ \\
\hline & No & $32(54.2)$ \\
\hline
\end{tabular}




\begin{tabular}{|l|l|l|}
\hline Outpatient department visit in last year & $1-4$ & $25(42.4)$ \\
\hline & $5-8$ & $03(5.1)$ \\
\hline & $>8$ & $05(8.5)$ \\
\hline & No & $26(44.0)$ \\
\hline
\end{tabular}

The study consisted of 207 asthmatic patients who attending the medical clinic Teaching hospital Batticaloa. Among this sample population $148(71 \%)$ of them are well controlling their asthma rest of them (29\%) are not well control.

In this sample population $35(59.3 \%)$ of them were 35-64 years old age group and $21(35.6 \%)$ of them were more than 65 years old. Females represent $69.5 \%$ rest of them are males. Majority $(74.57 \%)$ of them were Tamils. Most of them $(55.9 \%)$ of them finished up to grade five to GCE ordinary level. In not well-controlled asthmatic patients, $74.6 \%$ of them were married and $27.1 \%$, they were earning less than Rs.5000 and Rs.5001 to Rs.9999 per month.

In this population $33(55.9 \%)$ of them state that no one have asthma in their family on the other hand $26(44.1 \%)$ of them state their family members having asthma. Most of them (37.3\%) admitted to hospital 1-2 times during last year due to uncontrolled asthma. $42.4 \%$ of them were visited 1-4 times in outpatient department to treat their asthma exacerbation.

Figure 01 illustrates among not well control asthma patients only $27.12 \%$ of them got education, but others doesn't received any health education regarding asthma. Figure 03 explain among the patient who received health education in that by whom or where they received the information. Here $68.75 \%$ of the health education given by doctors and $18.75 \%$ of education given by nurses in Teaching Hospital Batticaloa.

Table 03 explain how asthma symptoms varies related to age among not well-controlled patients. When consider $35-$ 64 years old age category $82.4 \%$ are getting symptoms daily where in more than 65 years age category $52.4 \%$ are getting daily symptoms. In this category, $14.3 \%$ of them are getting symptoms 1-6 times per week.

Table 03 Age Vs Asthma symptoms

\begin{tabular}{|l|l|l|l|l|l|}
\hline \multicolumn{7}{|l|}{} & Symptoms of asthma & $\begin{array}{l}1-3 \\
\text { Age }\end{array}$ & Daily & $\begin{array}{l}1-6 \\
\text { times/week }\end{array}$ & $\begin{array}{l}\text { Only with a Upper } \\
\text { respiratory infection or } \\
\text { weather change }\end{array}$ \\
\hline $18-34$ & $1(33.3 \%)$ & 0 & $1(33.3 \%)$ & 0 & $1(33.3 \%)$ \\
\hline $35-64$ & $28(82.4 \%)$ & $2(5.9 \%)$ & $3(8.8 \%)$ & $1(2.9 \%)$ & 0 \\
\hline$>65$ & $11(52.4 \%)$ & $3(14.3 \%)$ & $4(19.0 \%)$ & 0 & $3(14.3 \%)$ \\
\hline
\end{tabular}

Figure 04 explain about the triggering factors of asthma among not well control asthmatic patients. $35 \%$ of them state their asthma trigger by weather condition on the other hand $33 \%$ of them told that allergens such as pets, mice, cockroaches, dust, mold and cleaning supplies are triggering their disease.

Figure 05 describe about spacer device usage related to age. Here more than 65 years old, only $6.8 \%$ of them are using spacer device while inhaling their medication. But others not using at all.

Table 04 Knowledge regarding asthma prevention and management comparison with well controlled and not well controlled group.

\begin{tabular}{|l|l|l|l|l|l|l|l|}
\hline $\begin{array}{l}\text { Knowledge regarding } \\
\text { asthma prevention and } \\
\text { management }\end{array}$ & $\begin{array}{l}\text { Level } \\
\text { of } \\
\text { control }\end{array}$ & $\begin{array}{l}\text { Not } \\
\text { helpful } \\
\mathbf{N}(\boldsymbol{\%})\end{array}$ & $\begin{array}{l}\text { Slightly } \\
\text { helpful } \\
\mathbf{N}(\boldsymbol{\%})\end{array}$ & $\begin{array}{l}\text { Moderately } \\
\text { helpful } \\
\mathbf{N}(\boldsymbol{\%})\end{array}$ & $\begin{array}{l}\text { Quite } \\
\text { helpful } \\
\mathbf{N}(\boldsymbol{\%})\end{array}$ & $\begin{array}{l}\text { Extremely } \\
\text { helpful } \\
\mathbf{N}(\boldsymbol{\%})\end{array}$ & $\begin{array}{l}\boldsymbol{p} \text { - } \\
\text { value }\end{array}$ \\
\hline $\begin{array}{l}\text { Taking preventive } \\
\text { medicines every day }\end{array}$ & $\mathrm{W}$ & $03(60)$ & $03(60)$ & $11(73.3)$ & $79(69.9)$ & $51(75)$ \\
\cline { 2 - 7 } & $\mathrm{NW}$ & $02(40)$ & $02(40)$ & $04(26.7)$ & $34(30.1)$ & $17(25)$ \\
\hline $\begin{array}{l}\text { Avoiding things that } \\
\text { cause allergic reactions }\end{array}$ & $\mathrm{W}$ & $07(100)$ & $14(60.9)$ & $31(75.6)$ & $62(66)$ & $33(80.5)$ \\
\cline { 2 - 8 } & $\mathrm{NW}$ & 0 & $09(39.1)$ & $10(24.4)$ & $32(34)$ & $08(19.5)$ \\
\end{tabular}




\begin{tabular}{|l|l|l|l|l|l|l|l|}
\hline \multirow{2}{*}{$\begin{array}{l}\text { Using your quick relief } \\
\text { medication }\end{array}$} & $\mathrm{W}$ & $03(75)$ & $03(60)$ & $05(83.3)$ & $45(66.2)$ & $90(73.8)$ & 0.737 \\
\cline { 2 - 7 } & $\mathrm{NW}$ & $01(25)$ & $02(40)$ & $01(16.7)$ & $23(33.8)$ & $32(26.2)$ & \\
\hline $\begin{array}{l}\text { Seeing a doctor regularly } \\
\text { even if you are in good } \\
\text { health }\end{array}$ & $\mathrm{W}$ & $03(100)$ & $10(100)$ & $22(66.7)$ & $94(68.6)$ & $16(80)$ & 0.146 \\
\cline { 2 - 8 } & $\mathrm{NW}$ & 0 & 0 & $11(33.3)$ & $43(31.4)$ & $4(20)$ & \\
\hline Taking inhalers & $\mathrm{W}$ & $05(71.4)$ & 0 & $02(100)$ & $36(63.2)$ & $104(75.9)$ & $0.021^{*}$ \\
\cline { 2 - 7 } & $\mathrm{NW}$ & $02(28.6)$ & $03(100)$ & 0 & $21(36.8)$ & $33(24.1)$ & \\
\hline
\end{tabular}

W- Well controlled, NW- Not well controlled, * 95\% significant level

Most of the well-controlled patients $(75 \%)$ of them are agreed that taking preventive medicine every day it is extremely helpful to them but not well control $25 \%$ them agreed that statement. Eighty percentage of the wellcontrolled patients avoiding the allergens, in not well controlled category only $19.5 \%$. Quick relief medicine is extremely helpful to $73.8 \%$ of the well-controlled group where only $26.2 \%$ in not well-controlled group. Eighty percentage of well-controlled patients meeting the doctor regularly when they do not have asthmatic symptoms. However, in not well-controlled category only $20 \%$ are meeting the doctor.

Taking inhaler is extremely helpful to $75.9 \%$ well controlled people where $24.1 \%$ of them in not well-controlled group state that taking inhaler is extremely helpful and also taking inhaler is having statistically significant association with level of asthma control.

Table 05 Point of drug inhalation vs level of asthma control.

\begin{tabular}{|l|l|l|}
\hline When do you start treating when you get the Asthma & Well controlled & Not well controlled \\
\hline When started coughing & $58(73.4 \%)$ & $21(26.6 \%)$ \\
\hline When started wheezing & $17(53.1 \%)$ & $15(46.9 \%)$ \\
\hline When had difficulty breathing & $72(75.8 \%)$ & $23(24.2 \%)$ \\
\hline
\end{tabular}

Chi-Square $=6.282$, $\mathrm{p}$-value $=0.043$

Most (73.4\%) of well controlled patient getting puff when they feel coughing but only $26.6 \%$ taking puff in not well controlled category. The point where they are taking the puff also having statistically significant association with level of asthma control.

\section{Discussion:-}

The purpose of this cross sectional descriptive study was to identify influencing factors among poor asthma control patients who were following medical clinic at teaching hospital Batticaloa. Inhaler usage and appropriate time of taking medication are having a statistically significant association with not well asthma control where other variables does not show any statistically significant relationship.

In our study showed that $29 \%$ of the patients with asthma had not well-controlled asthma.

Asthma self-management education is necessary to provide persons with asthma and caregivers with the knowledge and skills to control and manage asthma $(8,9)$. In our study respondents reported that low self-management education was given by health care providers; only $27.1 \%$ of the respondents received education in not wellcontrolled asthma group rest of them (72.8\%) were not received health education.

Jamaan M Al-Zahrani et al (14) state in their study most of the education was received from physician (68\%) with much less education received from the asthma educators. Same finding was seen in our study too most of the patient get educated from doctors rather than other health care professionals.

In well-controlled group $80 \%$ said, that meeting doctor is extremely helpful to them same finding obtained the study conducted by Al-Jahdali and colleagues (15)in the emergency setting, the majority of patients (81.4\%) had a regular follow-ups in the community care clinic for asthma management. 


\section{Conclusion:-}

In this study population, $29 \%$ of them are not well controlling their asthma disease and most of them (2.8\%) does not received health education from the health care providers.

Inhaler usage and appropriate time of taking medication have statistically significant relationship with not wellcontrolled asthma it shows that their education, inhaler usage and proper time of inhalation of medicine have impact on poor asthma control.

In our study when we consider about the outpatient department visit in last year in not well control category $42.4 \%$ of them visited 1-3 times and received medical care. Patients who attending regularly to consult doctor, $80 \%$ of well-controlled patient stated it is extremely helpful to them. This brought the finding that when patient Poor attendance to the doctor due to poor symptom perception, failure of the physician to adhere to treatment guidelines, insufficient adherence by children and parents and the presence of extremely severe, therapy-resistant disease have all been proposed as possible reasons for suboptimal asthma control $(10,11-13)$.

\section{Recommendation:-}

The health education programme has much effect on asthma control and symptom management. Therefore, we have to provide optimum knowledge not only in health sectors but also in schools. We have to conduct screening programme annually that is more effective in controlling symptoms and prevent from complications.

\section{References:-}

1. World Health Organization. (2018). Non communicable diseases. [online] Available at: http://www.who.int/mediacentre/factsheets/fs355/en/ [Accessed 1 Jan. 2018].

2. World Health Organization. (2018). Asthma. [online] Available at: http://www.who.int/mediacentre/factsheets/fs307/en/ [Accessed 1 Jan. 2018].

3. National Heart, Lung, and Blood Institute, National Institutes of Health. National Asthma Education and Prevention Program. Expert Panel Report 3: Guidelines for the diagnosis and management of asthma (2007), NIH Publication No. 07-4051.

4. Asthma in Sri Lanka -World Life Expectancy [online] Available at: http://www.worldlifeexpectancy.com/srilanka-asthma [Accessed 15 July. 2016].

5. Sri lanka health at a glance (2008) volume1, ISSN 2012-6697

6. National survey on self reported health (2004)

7. NAEPP Guidelines for the Diagnosis \&Management of Asthma Expert Panel Report-3. (2007). [online] Available at:www.nhlbi.nih.gov/guidelines/asthma. [Accessed 15 Feb. 2016].

8. Canonica GW, Baena-Cagnani CE, Blaiss MS, Dahl R, Kaliner MA, Valovirta EJ. (2007) Unmet needs in asthma: Global Asthma Physician and Patient (GAPP) Survey: global adult findings. Allergy, 62(6):668-674.

9. Steurer-Stey C, Fletcher M, Vetter W, Steurer J. (2006) Patient education in asthma: a survey of physicians' knowledge of the principles and implementation of self management in practice. Swiss Med Wkly, 136(3536):561-565.

10. Legorreta AP, Christian-Herman J, O9Connor RD, Hasan MM, Evans R, Leung KM. (1998) Compliance with national asthma management guidelines and specialty care: a health maintenance organization experience. Arch Intern Med, 158: 457-464.

11. Cockcroft DW, Swystun VA. (1996) Asthma control versus asthma severity. J Allergy Clin Immunol, 98: 1016-1018.

12. van Schayck CP, van Der Heijden FM, van Den Boom G, Tirimanna PR, van Herwaarden CL. (2000) Under diagnosis of asthma: is the doctor or the patient to blame? The DIMCA project. Thorax, 55:562-565.

13. Goodman DC, Lozano P, Stukel TA, Chang C, Hecht J. (1999) Has asthma medication use in children become more frequent, more appropriate, or both? Pediatrics, 104: 187-194.

14. Jamaan M Al-Zahrani, Anwar Ahmad, Abdullah AL-Harbi et al, (2015) Factors associated with poor asthma control in the outpatient clinic setting, 10 (2) : 100-104.

15. Al-Jahdali H, Anwar A, Al-Harbi A, Baharoon S, Halwani R, Al Shimemeri A, et al. Factors associated with patient visits to the emergency department for asthma therapy. BMC Pulm Med 2012;12:80. 